ISSN: 2600-5859

\title{
Aula invertida de educación superior: una revisión de literatura reciente
}

\author{
Higher education trough flipped classroom: a review of recent literature \\ José Luis Andrade Mendoza. ${ }^{1}$, Lorena Maribel Yumi Guacho. ${ }^{2}$, Rosa Belén Ramos Jiménez. ${ }^{3}$ \\ Recibido:05-01-2020 / Revisado:22-01-2020 /Aceptado: 03-02-2020/ Publicado: 05-03-2020
}

\begin{abstract}
DOI: https://doi.org/10.33262/concienciadigital.v3i1.2.1180
An innovative approach of learning in higher education level is certainly flipped classroom, the application of new technology in the educational field is helping educations with real advantages in this digital era that engages learners and tutors in flipped classroom learning. The present study assesses an efficient revision of the bibliography on the flipped classroom, with the aims of advantages with its challenges that face two main actors; university learners and professors. The effect of the flipped model and its improvement to higher education is conducted on the interest of its operation in several academic fields. It is discussed the advantages and interests of the flipped model in teaching contents breaking the traditional model with the access and application of technological tools in the academic context. The research concludes with a suggestion based on the influence of technology as a resource of learning acquisition and the evidence of improvement in learner's academic lives with the performance and practice of the flipped model approach.
\end{abstract}

Keywords: Flipped classroom, Higher education, inverted classroom, active learning.

\section{Resumen}

Un enfoque innovador de aprendizaje en el nivel de educación superior es sin duda el aula invertida, la aplicación de nuevas tecnologías en el campo educativo está ayudando a las educaciones con ventajas reales en esta era digital que involucra a los estudiantes y tutores en el

\footnotetext{
${ }^{1}$ Escuela Superior Politécnica de Chimborazo, Faculty of Computer Science and Electronics. Riobamba, Ecuador. jose.andrade@espoch.edu.ec

2 Escuela Superior Politécnica de Chimborazo, Faculty of Computer Science and Electronics. Riobamba, Ecuador. 1o.yumig@espoch.edu.ec

${ }^{3}$ Escuela Superior Politécnica de Chimborazo, Faculty of Computer Science and Electronics. Riobamba, Ecuador. rosa.ramos@espoch.edu.ec
} 
aprendizaje invertido en el aula. El presente estudio evalúa una revisión eficiente de la bibliografía en el aula invertida, con el objetivo de ventajas con sus desafíos que enfrentan dos actores principales; Estudiantes universitarios y profesores. El efecto del modelo invertido y su mejora en la educación superior se lleva a cabo en interés de su funcionamiento en varios campos académicos. Se discuten las ventajas e intereses del modelo invertido en la enseñanza de contenidos que rompen el modelo tradicional con el acceso y la aplicación de herramientas tecnológicas en el contexto académico. La investigación concluye con una sugerencia basada en la influencia de la tecnología como un recurso de adquisición de aprendizaje y la evidencia de mejora en la vida académica del alumno con el desempeño y la práctica del enfoque de modelo invertido.

Palabras clave: Aula invertida, educación superior, aula invertida, aprendizaje activo.

\section{Introduction}

The flipped classroom nowadays represents a modern pedagogical approach that changes the entire model class, where learners work in an active form through the correct use of technological sources found on internet, in contrast of the traditional learning model where the participation of learners are passive and professors become the center of the class, the instructions are given straight. Education at University motivates their professors and leaners in updated approaches that enhance acquisition of diverse teaching models, the idea to improve their students learning skills into a new era, where regular classes are switched or flipped. The benefit of video podcast on the platform YouTube motivate students in a practice different learning skill.

In this article, it is reported the innovation of flipped classroom-focused in the production of learning acquisition skills where the enjoyment of students in their learning process showing their satisfaction and their motivation in their learning style.

An analysis of recent literature based on flipped class is presented in this research, in some other field it is found as an inverted class where higher education focuses the interest for its advantage that represents this model. The process of flipping a regular classroom class in higher education will be explained. Finally, the framework of our article follows a formal and classic form where we open our research with an important review of updated literature followed by the description of the methodology applied, presenting the conclusions that will help further academic studies. 


\section{Literature review}

The term of Flipped classroom model is formulated in the year 2007 by Bergmann and Sams, and it is detailed as a teaching approach breaking the traditional perspective of a common class where activities are completely acquired at home and reinforced in the class. (Bergmann and Sams, 2012; Davies et al., 2013).

Flipping a regular classroom has taken several forms between teaching and learning strategies in the class and the access to deliver a full class in an online mode through technological tools (Awidi $\&$ Paynter, 2019). The flipped approach has taken an imperative connotation in the education field breaking the traditional stereotype among educators worldwide. In the same background, Goh \& Ong (2019) in their study conducted that flipped classroom also known as blended learning, students have more flexibility at the moment that integrates online learning activities. Under this context, blended learning combines online learning tasks including components such as video, games, podcasts, online reading material and online assignments helping learners access anywhere or everywhere as long as the internet access is available, nevertheless, online learning does not replace face to face learning style the inclusion of this method and traditional method complement each other and work complementary together turning flipped classroom as an inclusive learning experience.

He, Holton, Farkas, \& Warschauer (2016) asserted that the essence over flipped instructions begins with the ability to combine online instructions and activities designed in the class turning in the design of new material. Also, the authors highlighted the interest over flipped pedagogy that combines the flexibility of the integration of authentic material, its benefit of online instruction with active learning teaching techniques and the construction of use of knowledge.

\section{Flipping a regular class in higher education}

Uzunboylu \& Karagozlu (2015) assert that flipped classroom provides different learning styles especially the application of learning technology, in this circumstance, the authors reveal that flipped model encourage learners into important learning activities where they find themselves their learning style because it causes great interest in the subject matter. Under this concept, flipped classrooms are not only essentially appropriate for all classes in the higher education context, because all depends on what activities and contents are designed for the class, nevertheless, but the accurate application in a flipped model also represents as an important academic tool in its 
educational scenery. Additionally, Uzunboylu \& Karagozlu consider that teaching and learning process under the flipped classroom must follow the lower levels of Bloom's Taxonomy where the production of the English language is evidenced, the understanding of new contents in the target language is identified and learners can remember the elemental concepts outside the class, which in this case internet represents strongest instrument for an easy access of information, in contrast, the scenery inside the class where higher-order levels are applied, learners can create their knowledge, their communication skills are evaluated, and their cognition levels are mostly analyzed by their content professors.

The consideration of flipping a traditional class, Frisby \& Martin (2010) reveals that students need wide feedback in the guidelines provided by their instructors, making the flipping class as an essential supportive tool when feedback is needed in learning perspective.

\section{The application of technology in a flipped class}

As a manner of fact, higher education goal focuses the effort based on the application of technical sources where students applied these tools found on the internet such as online videos and web pages, the authors remark the advances in technological field motivate learners in the application of video lectures outclass in-person lectures, with cooperative online videos. In this context, Online homework represents an assertive role in contrast to paper-and-pencil homework, and wisely conducted into smart training systems become as current as of the presence of teachers. (Bishop $\&$ Verleger, 2013). Flipped class in higher education highlights the effective results when feedback is combined between the interaction of student's production of knowledge and teacher's work that encourages connection between outdoors class activities and indoors class.

Abeysekera \& Dawson (2015) advocate the view that flipped classroom approaches have the total attention becoming a popular figure of education, due to its term since its origin around 2011 develop its popularity on Google the most researched term in the web increasing its search until its potential work expose its ideal results. The authors present arguments to emphasize that the flipped classroom discharge the conventional endemic reading style, where a lecture is replaced trough an active approach which activities are done in the class during their pre-classes (before class) and post-classes (after class activities). Another key point is presented when the flipped classroom personifies the transference of information- directly to students in the habitual face-toface lecture or commonly known as the traditional lecture. The application of this approach 
ISSN: 2600-5859

certainly moves the acquisition of new content in a different schedule which is learned out of class time. As an illustration, it can be seen that the role of students under the present model is placed more active and collaborative tasks connecting with engaging resources that invert the common lecture, with these intention leaners can consolidate their knowledge after class.

Beenen \& Arbaugh, (2019) finding maintain that the flipped class model denotes to a pedagogical method that uses material such as lecture applied as a reading for reading and reading for leisure, this material is conducted oppositely through the traditional classroom, with in-class instruction focused on deeper processing and application of class content. The authors suggest that the target is to "flip" all the possible classwork and the task sent as homework with activities (readings) done outside of class and applied with the appropriated material in class.

Furthermore, Lai \& Hwang (2016) suggest that the educational paradigm has rearranged from teacher instruction mode to student-centered learning constructing the term "flipped classroom" as a learning approach that substituted the time spent in the construction of basic knowledge in class into academic time in doing homework or producing knowledge. Certainly, the authors establish that flipped classrooms have two modes of learning: Outclassss and In -class.

· The "Out of class learning":

The students learning process is acquired through watching videos, web-based instructions or other descriptive materials. Students take control their time and learning process because their capacity of recollecting the information and understand the contests are truly affected.

· The "In class learning":

The student's presence in the class represents an essential element of the mentioned model class due to student's performance is evidenced according to their development, the activities accomplished and their performance in the class based on their capacity in giving appropriate solutions.

Regarding "In-class and Out-class" in a flipped model class, Akçayır \& Akçayır (2018) believe that there is a variety of activities to apply in flipped class style, especially activities where the 
appropriate learning is activated which in this case can be correctly effective with in-class and outclass.

Freeman \& Herreid, (2013) mention in their study that all the activities designed for the flipped classroom are mostly chosen according to the technology available and the complexity, in this case, homework can use readings and videos, those must be wisely tailored for the students to get them ready for the in-class activities. In the same path, the best option of choice for most students and teachers referring out - of class activities certainly are videos that explain clearly the activities instead of the old-fashioned lecture method.

The flipped classroom as an instructional model has developed a positive alternative in learning process in contrast to predictable lecture-based teaching, this model has been also understood by academic researchers as the inverted classroom because the fast proliferation in Internet access and advances in online technology is well seen, also it presents an opportunity to consider the way of our classes the teaching methodology and learning results especially in the context of higher education.

Galway, L. P., Corbett, K. K., Takaro, T. K., Tairyan, K., \& Frank, E. (2014) mentionated that in the last ten years, the interest of this framework has increased the collaborative and active learning through the use of online learning strategies and technologies where in-class learning is incorporated with updated learning experiences.

Equally important, Gilboy, Heinerichs, \& Pazzaglia (2015) asserted that in higher education outcomes flipped classroom increases that student learning level, as an example the authors confirm when students and teachers promote this approach at the moment that surveys are applied. The authors highlighted the results of the development of student and professors according their interactions, the contact of each other in real-time give the opportunity to correct their possible mistakes and reinforce any doubt, the result definitely increased learner's engagement by the production of the target language.

Discussing flipping the classroom approach, the authors assert that students study instructional material before class those can be conducted through watching online lectures and more, after that in class leaners can apply the material learned with previous time during the class. Flipping the 
class give a great popularity to professor of a new era because the results of this approach are highly positive. (van Alten, Phielix, Janssen, \& Kester, 2019)

The view of flipped classrooms in higher education, the author suggests that in-class activities studies often conduct on students their effort in satisfaction and learning outcomes. (Bouwmeester, 2019). The starting point in this learning process is the intrinsic motivation that students find in themselves, enhancing motivation is conducted through the learner's autonomy and teacher's competence. When learners prepare and plan these activities for the class, they feel free to manage their place and time, also the freedom to choose from different study materials increasing their autonomy in learning choice. Likewise, (Chilingaryan \& Zvereva, 2017) study point out that flipping a class represents a creative functional atmosphere because the combination of information in technology and creative working contributes to the construction of an appropriate example of an inverted class. In this stage, the participation of both actors (teachers and students) is vital for the achieved result. As a manner of fact, the teacher can create by himself videos or podcasts either a short duration, it means that the video is going to be no longer than 5-10 minutes on activities because students will be able to work independently checking, reviewing and listening at the content at home. Finally, learners will rise and clarify their questions based on the structure of the contents of the teacher, in this manner students will motivate the entire class to formulate questions individually with a specific goal which is the clarification and solving the doubts of each student.

Camiling (2017) mentions that students these days have free access to technological advancements tools, these sources give teachers great demand in the application of new technologies involving the request of new design of teaching-learning methods.

The authors assert that this is an educator's evidence where the 21st century motivates their learners' efficient management and application of technological sources where they can be done to enhance the production of contents in any form.

The benefits in the principles for the flipped classroom are advocated by Kim, Kim, Khera \& Getman (2014) follows:

- Learners are given more opportunities to obtain elemental information before the class. 
- The real motivation is developed by learners when they watch online lectures and get ready before class.

- Professors are able to organize their own methods or approaches according the flipped class.

- The autonomy that represents this model make connecting in-class activities with out-ofclass work.

- The construction of an ideal study environment is promoted by professors in their field.

- The improvement of feedback is motivated from teachers to learners, this feedback can be individual or group works.

\section{Conclusions}

The review of the literature reveals that students at the university find themselves motivated to increase their learning process out of the classroom instead of the traditional model that is evidenced inside the class due to the independence and autonomy developed by leaners through the correct management of place and time.

The flipped classroom is considered as an instructional approach for use in higher education level, this active learning model is effective for enhancing the acquisition of independent thinking in university students. A successful classroom design trough the flipped approach can be executed in consideration of the precise learning objectives in the class. (Rawas, Bano, \& Alaidarous, 2019). The results based on the literature review open more opportunities to be studied in the academic field where flipped classroom pattern interchange the direct instruction implemented by teachers in class, the application of technological sources which in most of the cases videos are accessed for learners who find more advantages in this model than a regular class because they analyze all the instruction in an autonomous learning environment at anytime and anyplace (Bergmann \& Sams, 2012; Hamdan et al., 2013).

It is notorious the analysis of this method because it pointed several disciplines where professors at the university and students in the classroom are interested in the reinforcement of knowledge and the interaction not only presential class because the principal objective is to produce autonomous learning and guide study with improvement in the teaching-learning process. 


\section{Bibliographic references}

Abeysekera, L., \& Dawson, P. (2015). Motivation and cognitive load in the flipped classroom: definition, rationale and a call for research. Higher Education Research and Development, 34(1), 1-14. Retrieved from https://doi.org/10.1080/07294360.2014.934336

Alten, D., Phielix, C., Janssen, J., \& Kester, L. (2019). Effects of flipping the classroom on learning outcomes and satisfaction: A meta-analysis. Educational Research Review, 28(May), 1-18. Retrieved from https://doi.org/10.1016/j.edurev.2019.05.003

Akçayır, G., \& Akçayır, M. (2018). The flipped classroom: A review of its advantages and challenges. Computers and Education, 126(January), 334-345. Retrieved from https://doi.org/10.1016/j.compedu.2018.07.021

Awidi, I. T., \& Paynter, M. (2019). The impact of a flipped classroom approach on student learning experience. Computers and Education, 128(September 2018), 269-283. Retrieved from https://doi.org/10.1016/j.compedu.2018.09.013

Beenen, G., \& Arbaugh, B. (2019). Flipping class: Why student expectations and personsituation fit matter. International Journal of Management Education, 17(3), 100311. Retrieved from https://doi.org/10.1016/j.ijme.2019.100311

Bergmann, J., \& Sams, A. (2008). Remixing chemistry class. Learning and Leading with Technology, 36(4), 24-27.

Bishop, J., \& Verleger, M. (2013). Testing the flipped classroom with model-eliciting activities and video lectures in a mid-level undergraduate engineering course. Proceedings - Frontiers in Education Conference, FIE, 161-163. https://doi.org/10.1109/FIE.2013.6684807

Bouwmeester, R. A. M., de Kleijn, R. A. M., van den Berg, I. E. T., ten Cate, O. T. J., van Rijen, H. V. M., \& Westerveld, H. E. (2019). Flipping the medical classroom: Effect on workload, interactivity, motivation and retention of knowledge. Computers and Education, 139(May), 118-128. Retrieved from https://doi.org/10.1016/j.compedu.2019.05.002 
Camiling, M. K. (2017). The Flipped Classroom: Teaching the Basic Science Process Skills to High-Performing 2nd Grade Students of Miriam College Lower School. IAFOR Journal of Education, 5(SI), 213-230. Retrieved from https://doi.org/10.22492/ije.5.si.10

Chilingaryan, K., \& Zvereva, E. (2017). Methodology of Flipped Classroom as a Learning Technology in Foreign Language Teaching. Procedia - Social and Behavioral Sciences, 237(June 2016), 1500-1504. Retrieved from https://doi.org/10.1016/j.sbspro.2017.02.236

Freeman, C., \& Herreid, N. A. S. (2013). Case Studies and the Flipped Classroom. Journal of College Science Teaching, 42(5), 62-66.

Frisby, B. N., \& Martin, M. M. (2010). Instructor - Student and student - Student rapport in the classroom. Communication Education, 59(2), 146-164. Retrieved from https://doi.org/10.1080/03634520903564362

Galway, L. P., Corbett, K. K., Takaro, T. K., Tairyan, K., \& Frank, E. (2014). A novel integration of online and flipped classroom instructional models in public health higher education. BMC Medical Education, 14(1), 1-9. Retrieved from https://doi.org/10.1186/1472-6920-14-181

Gilboy, M., Heinerichs, S., \& Pazzaglia, G. (2015). Enhancing student engagement using the flipped classroom. Journal of Nutrition Education and Behavior, 47(1), 109-114. Retrieved from https://doi.org/10.1016/j.jneb.2014.08.008

Goh, C., \& Ong, E. (2019). Flipped classroom as an effective approach in enhancing student learning of a pharmacy course with a historically low student pass rate. Currents in Pharmacy Teaching and Learning, 11(6), 621-629. Retrieved from https://doi.org/10.1016/j.cptl.2019.02.025

He, W., Holton, A., Farkas, G., \& Warschauer, M. (2016). The effects of flipped instruction on out-of-class study time, exam performance, and student perceptions. Learning and Instruction, 45, 61-71. Retrieved from https://doi.org/10.1016/j.learninstruc.2016.07.001

Kim, M., Kim, S., Khera, O., \& Getman, J. (2014). The experience of three flipped classrooms in 
ISSN: 2600-5859

an urban university: an exploration of design principles. The Internet and Higher Education, $22,37-50$

Lai, C. L., \& Hwang, G. J. (2016). A self-regulated flipped classroom approach to improving students' learning performance in a mathematics course. Computers and Education, 100, 126-140. Retrieved from https://doi.org/10.1016/j.compedu.2016.05.006

Rawas, H., Bano, N., \& Alaidarous, S. (2019). Comparing the effects of individual versus group face-to-face class activities in flipped classroom on student's test performances. Health Professions Education, (9), 1-9. Retrieved from https://doi.org/10.1016/j.hpe.2019.06.002

See, S., \& Conry, J. M. (2014). Flip My Class! A faculty development demonstration of a flipped-classroom. Currents in Pharmacy Teaching and Learning, 6(4), 585-588. Retrieved from https://doi.org/10.1016/j.cptl.2014.03.003

Uzunboylu, H., \& Karagozlu, D. (2015). Flipped classroom: A review of recent literature. World Journal on Educational Technology, 7(2), 142. Retrieved from https://doi.org/10.18844/wjet.v7i2.46

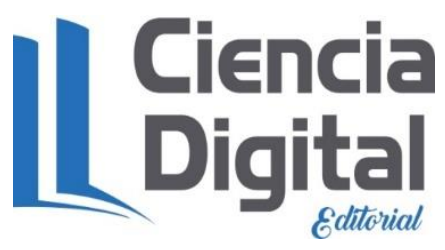


PARA CITAR EL ARTÍCULO INDEXADO

Andrade Mendoza, J. L., Yumi Guacho, L. M., \& Ramos Jiménez, R. B. (2020). Aula invertida de educación superior: una revisión de literatura reciente. ConcienciaDigital, 3(1.2), 80-91. https://doi.org/10.33262/concienciadigital.v3i1.2.1180

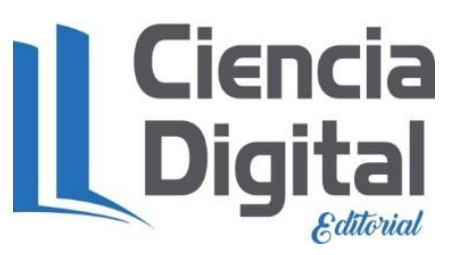

El artículo que se publica es de exclusiva responsabilidad de los autores y no necesariamente reflejan el pensamiento de la Revista Conciencia Digital.

El artículo queda en propiedad de la revista y, por tanto, su publicación parcial y/o total en otro medio tiene que ser autorizado por el director de la Revista Conciencia Digital.

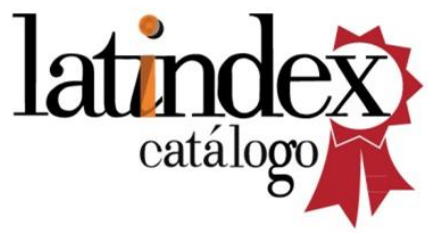

Conciencia

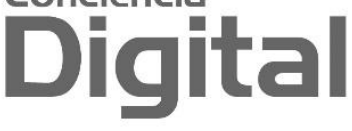

